\title{
RECENZJE
}

\section{Jan Mikołaj Wolski, Kultura monastyczna w późnośredniowiecznej Bułgarii, Wydawnictwo Uniwersytetu Lódzkiego, Lódź 2018, ss. 225+7 nlb. [= Byzantina Lodziensia, t. XXX].}

doi.org/10.14746/bp.2018.25.20

W Polsce badania nad początkiem i rozwojem chrześcijańskiego monastycyzmu mają wieloletnią tradycję. W ten nurt wpisuje się również prezentowana książka, która przedstawia ważny i rzadko dotąd podejmowany temat późnośredniowiecznego monastycyzmu bułgarskiego. Jej autorem jest Jan Mikołaj Wolski - historyk i paleoslawista młodego pokolenia, ale ze sporym już dorobkiem ${ }^{1}$. Recenzowana książka została oparta na jego dysertacji doktorskiej, przygotowanej pod kierunkiem prof. dr. hab. Mirosława J. Leszki i obronionej w lipcu w 2017 r. w Uniwersytecie Łódzkim.

Zamiarem Autora (s. 9) było ukazanie ideałów życia monastycznego, jakimi kierowali się bułgarscy mnisi w okresie między końcem XII a końcem XIV w. J. M. Wolski stara się odpowiedzieć na pytania: jaką uznawali oni hierarchię wartości oraz jaką rolę odgrywał przy tym etos monastyczny, prezentowany w analizowanych przez niego dokumentach. Kolejnym przedmiotem jego rozważań są obierane przez mnichów formy życia monastycznego. Ponadto próbuje ukazać, na ile społeczne zaangażowanie mnichów, w tym ich aktywność w działalności publicznej, godziły w wyznawane przez nich wartości.

Jeśli chodzi o zakres chronologiczny omawianej publikacji, Autor wyjaśnia, że dla niego zasadniczym punktem odniesienia był okres drugiego carstwa bułgarskiego, które funkcjonowało w latach 1185-1396. Badacz podkreśla (s. 10), że zignorował kryterium geograficzne na rzecz kryterium językowego, gdyż zjawisko dużej mobilności późnośredniowiecznych mnichów oraz fakt częstej zmiany granic państwowych nie pozwalały mu na precyzyjne wyznaczenie zasięgu terytorialnego.

W pierwszym rozdziale (s. 13-47) Autor szczegółowo przedstawia przeanalizowane przez siebie źródła w języku cerkiewno-słowiańskim. Należy podkreślić, że

1 Np.: Żywot św. Hilariona z Mogleny Eutymiusza Tyrnowskiego jako źródto do dziejów dwunastowiecznego bogomilizmu. Wiarygodność tekstu, „Słupskie Studia Historyczne” 17, 2011, s. 43-57; (Pseudo-)Basilian Rules for Monks in Late Medieval Bulgaria. A Few Remarks on a Bulgarian Nomocanon from the End of the 14th Century, „Palaeobulgarica” 36.2, 2012, s. 39-44; Autoproscoptae, Bogomils and Messalians in the 14th Century Bulgaria, „Studia Ceranea” 4, 2014, s. 233-241; Średniowieczne herezje dualistyczne na Bałkanach. Źródta stowiańskie, ed. G. Minczew, M. Skowronek, J. M. Wolski, Łódź 2015 . 
większość z nich jest nieznana polskim czytelnikom. Zostały one podzielone na trzy grupy. W pierwszej zawarł on teksty moralizatorskie i normatywne, które kształtowały określone wzorce zachowania. $\mathrm{W}$ drugiej znalazły się teksty hagiograficzne, w których opisano czyny i postawy sławnych mnichów, działających w omawianym okresie. Trzecią grupę stanowią żywoty świętych napisane lub przeredagowane przez bułgarskich mnichów. Według Uczonego odzwierciedlają one ówczesne poglądy na życie monastyczne.

W pierwszym rozdziale (s. 15-34) poświęca on także dużo uwagi odtworzeniu zakresu lektur, po które sięgali bułgarscy mnisi. Badacz słusznie zauważa (s. 16), że treść czytanych dzieł miała dla mnichów przede wszystkim „znaczenie formacyjne i budujące". Następnie odwołując się do słów Teodora Studyty zapisanych w Wielkich katechezach, wylicza cztery kategorie lektur, którym oddawali się bułgarscy mnisi, a mianowicie Pismo Święte, żywoty świętych, pouczenia „ojców” oraz teksty natury teologicznej. W celu bliższego zrekonstruowania listy preferowanych lektur, uczony przeanalizował zawartość zachowanych inwentarzy klasztornych bibliotek (s. 1722). Sam jednak dostrzega ograniczenia jakie niesie ze sobą ten rodzaj źródeł. Dają one jedynie cząstkowy obraz ze względu na ich niewielką ilość, a poza tym większość z nich pochodzi z klasztorów bizantyńskich ulokowanych w zachodnich Bałkanach oraz na górze Atos. Dlatego nie są one do końca reprezentatywne dla zakreślonych przez Autora ram chronologiczno-terytorialnych. W każdym razie, w zasobach klasztornych bibliotek przeważały księgi biblijne i liturgiczne. Poza tym wiele klasztorów bułgarskich dysponowało pewną ilością rękopisów spisanych po grecku, wśród których znajdowały się dzieła wschodnich Ojców Kościoła. W zbiorach bibliotecznych przeważały jednak przekłady na język cerkiewno-słowiańskim ich homilii, rozpraw i listów. Następnie uczony (s. 23-27) wskazuje na istotną rolę, jaką w życiu codziennym mnichów odgrywała lektura Pisma Świętego w tym Psalmów. Jednakże z danych (s. 33), jakie udało się mu pozyskać z zachowanych inwentarzy klasztornych, typikonów oraz rękopisów, wywnioskował, że oprócz różnych ksiąg Pisma Świętego i dzieł Ojców Kościoła, bułgarscy mnisi najchętniej sięgali po Drabinę raju autorstwa Jana Klimaka. Dzieło to można wręcz uznać za podręcznik życia monastycznego.

W dalszej części rozdziału pierwszego (s. 35-38) Autor poświęcił swoją uwagę tekstom normatywnym. We wskazanym fragmencie omówił on te, które regulowały klasztorną dyscyplinę. Typikony, które $\mathrm{m}$. in. były źródłem reguł nadawanych wspólnotom przez założycieli, się niestety nie zachowały. Dlatego Badacz odwołuje się w swojej książce do treści nomokanonów oraz ksiąg penitencjarnych, ze szczególnym uwzględnieniem rękopisów Nomokanonu CIAI 1160 oraz tzw. Kodeksu berlińskiego. Cenne jest to, że w tym miejscu streszcza on historię różnych redakcji nomokanonów, z których korzystały klasztory bułgarskie w późnym średniowieczu.

Na następnych stronach (s. 38-42) znajdujemy charakterystykę tekstów hagiograficznych, w których opisano dokonania i postawy sławnych mnichów, działających w omawianej epoce. Należą do nich: Żywot Joachima I; Żywot Grzegorza Synaity autorstwa patriarchy konstantynopolitańskiego Kaliksta I; Żywot Teodozjusza 
Tyrnowskiego tegoż samego autora; Żywot Romiła Widyńskiego napisany przez Grzegorza Kaligrafa; $\dot{Z} y$ wot Efrema zredagowany przez Marka Pećkiego i Stowo pochwalne Eutymiuszowi, które spisał Grzegorz Cambłak.

Kolejną przeanalizowaną grupą źródeł są żywoty świętych napisane lub przeredagowane w XIII i XIV wieku (s. 42-46). Jana M. Wolski zauważa, że chociaż opisują one osoby i wydarzenia ze wcześniejszych epok historycznych, to jednak oddają pogląd późnośredniowiecznych autorów na życie monastyczne. Jest to wniosek w pełni uzasadniony, gdyż w świecie wpływów bizantyńskich już w późnej starożytności zdarzało się, że podczas przeredagowywania kościelnych dokumentów starszej proweniencji, często dostosowywano je do aktualnych realiów. Wśród scharakteryzowanych przez Badacza żywotów możemy m.in. wymienić: Żywot Doroteusza, Żywot Symeona Saloity Leoncjusza z Neapolis, Żywot Gabriela Lesnowskiego, Żywot Barbarosa Pelagonijskiego czy Żywot Joachima Osogowskiego.

Rozdział pierwszy kończą rozważania dotyczące (s. 46-47) dokumentów donacyjnych, do których należą chryzobulle carów bułgarskich.

Rozdział drugi zatytułowany „Kultura monastyczna” (s. 49-150) stanowi główną część niniejszej książki. Niezwykle interesujące spostrzeżenia znajdujemy już na samym jego początku (s. 49). jego wstępie. Autor stwierdza, że mnisi bułgarscy w późnym średniowieczu posiadali monopol na działalność piśmienniczą i translatorską, przez co kulturę monastyczną możemy utożsamiać z kulturą wysoką, a samych mnichów z elitami intelektualnymi. Wyjaśnia przy tym, że nie były to elity intelektualne w dzisiejszym znaczeniu, gdyż ich twórczość ograniczała się przede wszystkim do ich własnego środowiska.

Następnie J.M. Wolski analizuje ideały jakie przyświecały ówczesnym mnichom (s. 50-82). Podkreśla on (s. 50), że ich życie było podporządkowane zabieganiu o zbawienie duszy. Jest to zresztą podstawowa teza omawianej książki, iż mnisi przejawiali nastawienie pragmatyczne, które polegało na ascetycznym doskonaleniu się dla osiągnięcia zbawienia. Dążenie do świętości było dla nich najważniejszym ideałem. Dlatego tak ważne było, żeby mnisi w swoim życiu odzwierciedlali różne cnoty (s. 52-56), w tym te kardynalne, które za św. Pawłem powtórzył Jan Klimak, czyli wiarę, nadzieję i miłość. Poza tym powinny im towarzyszyć inne praktyki (s. 57), jak modlitwa, umartwianie ciała, pokuta, oddalenie od ludzi, milczenie, czystość i wstrzemięźliwość seksualna. Tym, którzy żyli we wspólnotach zalecano okazywanie pokory, posłuszeństwa i gorliwości.

Na kolejnych stronach (s. 59-71) Jan M. Wolski drobiazgowo analizuje reguły, dotyczące wyobcowania i wyrzeczenia się świata przez mnichów. Badacz słusznie stwierdza (s. 63), że kseniteia i anachoreza nie wiązały się tylko ze zmianą miejsca zamieszkania. Były przede wszystkim „dyspozycją umysłu”. Wyrzekając się świata mnich nie tylko przeprowadzał się za mur klasztorny, ale odcinał się od innych żyjąc w celibacie, ubóstwie oraz w posłuszeństwie wobec przełożonego. Bardzo interesującym wątkiem poruszonym w tej książce są reguły (s. 65), które dotyczyły relacji pomiędzy mnichami w klasztorach. Z jednej strony poczucie wspólnoty musiało być 
bardzo silne. Z drugiej, kładziono duży nacisk na wyobcowanie każdego brata. Nie mogli oni nawiązywać zbyt zażyłych przyjaźni. Mieli o sobie za dużo nie wiedzieć. Nie wolno im było się śmiać, rozmawiać w czasie pracy, posiłków i w drodze dokądkolwiek. Czas wolny powinni byli spędzać w swoich celach.

Życie monastyczne nie było jednak wolne od sprzeniewierzania się ideałom oraz łamania reguł. Opisy kar przewidywanych za popełnianie grzechów (s. 67-68) pokazują, że dużym problemem dla mnichów było utrzymywanie czystości myśli oraz wstrzemięźliwość seksualna. Wielu z nich łamało też śluby ubóstwa (s. 72) parając się handlem i lichwiarstwem. A jeszcze inni mieli problem z okazywaniem posłuszeństwa przełożonym. Stąd ważne było okazywanie skruchy za popełnione złe postępki, które miało być połączone z praktykowaniem pokuty. Badacz słusznie zakłada (s. 75), że we wspólnotach decydujące zdanie na temat jej wymiaru mieli przełożeni. Mogli wydłużyć lub skrócić okres jej trwania. Jedną z najczęściej stosowanych praktyk pokutnych był post (s. 77).

W dążeniu do wypełniania ideałów miała pomagać mnichom modlitwa. Autor zauważa, że „modlitwa obok pracy i czytania, wypełniała znaczną część dnia mnicha, choć trudno na podstawie dostępnych nam źródeł określić dokładnie jaką" (s. 78). Traktowano ją jako mistyczne zjednoczenie z Bogiem. Dlatego Jan Klimak zalecał w Drabinie raju, żeby mnisi modlili się często i przestrzegali wyznaczonych na to godzin.

W następnej części książki (s. 82-101) Badacz przedstawia różne style życia monastycznego, jakie preferowali bułgarscy mnisi. Z analizy źródeł wynika, że w późnośredniowiecznej Bułgarii podstawowym stylem mniszej egzystencji był cenobityzm. Na czele wspólnoty zazwyczaj stali igumeni, choć w tytulaturze przełożonych spotykamy również archimandrytów i protosów. Autor przedstawia ich obowiązki oraz charakteryzuje hierarchię poszczególnych funkcji pełnionych przez braci w klasztorach (s. 84-89). Następnie poświęca swoje rozważania zjawisku anachorezy (s. 8992). Jak jednak wcześniej stwierdza (s. 82), pobyty w pustelniach w tym okresie należały do rzadkości, zaś miejsca odosobnienia (eremy, wieże, hezychasteriony) były najczęściej w jakimś stopniu powiązane monastyrami (s. 82). Wśród stylów życia monastycznego, których opisy znajdują się w źródłach, Jan M. Wolski wyszczególnia i omawia jeszcze: hezychazm i semianachoretyzm (s. 93-96). Jeśli chodzi o ewolucję stylów monastycznej egzystencji, to na podstawie wielu przesłanek, Badacz wysuwa przypuszczenie, że w późnośredniowiecznych bułgarskich klasztorach musiał narastać problem idiorytmii (s. 96-101). Jego zdaniem wiązało się to z rozwojem herezji, które określano mianem mesalianizmu lub bogomilizmu (s. 100).

Bardzo istotną i obszerną częścią niniejszej książki jest fragment omawiający temat pozycji ruchu monastycznego w życiu publicznym oraz miejsce aktywności społecznej w życiu ówczesnych mnichów (s. 101-152). Do jego opracowania posłużyły teksty hagiograficzne, dokumenty donacyjne oraz nomokanony. Uczony stawia w tym miejscu (s. 103) bardzo trafne pytania: Czy swoją aktywnością w sferach społecznych mnisi sprzeniewierzali się swojemu powołaniu? Czy praktykowanie ra- 
dykalnej ascezy wykluczało jakiekolwiek zaangażowanie w doczesne sprawy świata? W pierwszej kolejności przedstawia informacje jakie znajdują się żywotach świętych (s. 104-132). Sylwetki znanych mnichów z XIII i XIV wieku Autor ukazuje w porządku chronologicznym. Możemy więc prześledzić dane na temat działalności: Joachima I Tyrnowskiego (s. 105-107); Grzegorza Synaity (s. 107-111); Teodozjusza Tyrnowskiego (s. 111-120); Romiła Widyńskiego (s. 120-123); Efrema Pećkiego (s. 124-125) i Eutymiusza Tyrnowskiego (s. 125-128). Są to postacie, które niewątpliwie miały ogromny wpływ na kształtowanie bułgarskiego monastycyzmu. Na postawie opisów ich życia i aktywności społecznej Jan M. Wolski rekonstruuje schemat kariery monastycznej (s. 128-129). Składała się ona z następujących etapów: wstąpienie do monasteru, okres formacyjny, rozwijanie cnót, pobyt w pustelni, działalność publiczna, obejmująca przewodzenie grupie anachoretów, posługa igumena lub założenie innego klasztoru. Bardzo często ostatnim etapem był powrót do życia pustelniczego. Uczony przyznaje, że podany przez niego schemat jest pewnym uogólnieniem, gdyż nie wszystkie drogi życiowe przebiegały w ten sam sposób. Niejednokrotnie zmianie ulegała kolejność etapów początkowych, bądź też po prostu w wyniku różnych okoliczności niektórych nigdy nie realizowano. Dalej Badacz wyjaśnia (s. 129-132), że działalność publiczna wspomnianych powyżej mnichów ograniczała się przede wszystkim do ich własnego środowiska. Jednak w pewnym momencie niektórzy z nich nawiązywali kontakt ze świeckimi wiernymi i obejmowali ich opieką duchową. Inne rodzaje mniszej aktywności społecznej obejmowały m.in. inicjowanie i nadzorowanie twórczości piśmienniczej, zwalczanie herezji, działalność duszpasterską, czy też pełnienie funkcji kościelnych np. patriarchy Tyrnowa. Oczywiście według hagiografów ci „boży mężowie” unikali jakiegokolwiek uwikłania w sprawy „tego świata”. Jednakże Autor słusznie zauważa, że te same źródła, jak też i inne dokumenty poświadczają, że nie do końca się to im udawało. Mnisi ciągle borykali się z wizytami wiernych i pielgrzymów, którzy zabiegali o ich błogosławieństwo; a ponadto oni sami niejednokrotnie uczestniczyli w synodach oraz często pełnili różne funkcje kościelne. Pewne jest jednak, że działalność na rzecz zewnętrznego świata, tego poza murami klasztoru, nigdy nie zdominowała ich życia. Zawsze na pierwszym miejscu było dobro wspólnoty monasteru, a na dalszym planie inne sprawy (s. 131).

Kolejnym istotnym wątkiem jest obraz społecznego znaczenia monastycyzmu bułgarskiego wyłaniający się z treści chryzobulli (s. 132-139). Przeprowadzona przez Badacza analiza tych dokumentów, pozwoliła na wyciągnięcie wniosku, że władcy bułgarscy postrzegali mnichów, jako orędowników u Boga. W przekonaniu carów ich modlitwy mogły zapewnić im opiekę samego Boga. Dlatego tak chętnie obdarowywali poszczególne klasztory. Przechowywane w monasterach relikwie uznawano za dodatkowy kanał łączności pomiędzy niebem a ziemią. W imieniu panujących zanoszono więc do świętych modlitwy w intencjach ochrony kraju przed wrogami, herezjami, chorobami i innymi nieszczęściami. W ten sposób działalność mnichów zyskiwała znaczenie państwowe. 
Jan M. Wolski podkreśla, że najważniejszym aspektem aktywności mnichów na rzecz świeckich była działalność duszpasterska (s. 139). Bracia modlili się o pomyślność żywych, jak i za dusze zmarłych, udzielali błogosławieństw chorym, radzili w codziennych sprawach życiowych, głosili kazania oraz spowiadali. Wierni okazywali im za to swoją wdzięczność w postaci darów i zapłaty. Źródła podają niewiele informacji na temat działalności charytatywnej bułgarskich klasztorów. Niemniej Autor słusznie podąża za swoją intuicją naukową stwierdzając (s. 144-145), że ta sfera działalności musiała wyglądać podobnie jak w klasztorach bizantyńskich. Chmary biedoty, żebraków i pielgrzymów potrzebowały przecież wsparcia w postaci jałmużny oraz lokowania w przytułkach i szpitalach przyklasztornych. Przykłady takiej działalności Badacz odnalazł w klasztorach Baczkowskim i Pakuriana (s. 145).

Badania przedstawione w niniejszej publikacji pokazują również, że w źródłach znajduje się niewiele informacji na temat działalności gospodarczej bułgarskich klasztorów (s. 147). Nie dowiemy się więc jak wyglądało zarządzanie majątkiem klasztornym oraz jakie były w nich dochody. Nie ma w nich też wiadomości na temat problemów dyscyplinarnych, jakie musiało rodzić posiadanie i obracanie majątkiem. Pewne jest natomiast, że bułgarskie klasztory posiadały znaczne majątki, w tym wsie, młyny, sady i lasy. O tym dowiadujemy się z dokumentów donacyjnych władców. $Z$ ich treści wynika także, że klasztorne posiadłości posiadały gwarancje prawne i ulgi fiskalne.

Zachowane rękopisy z klasztornych bibliotek, rzucają nieco więcej światła na działalność piśmienniczą prowadzoną w monasterach (s. 148). Mnisi pisali i kopiowali księgi. Z danych, których dostarczają podpisy kopistów, glosy marginesowe i kolofony, wynika, że w XIV wieku klasztory zmonopolizowały w Bułgarii działalność piśmienniczą. Kopie rękopisów wykonywano też na zamówienie osób świeckich i duchownych (s. 149).

Autor wyjaśnia (s. 149), że analizowane przez niego dokumenty nie dają możliwości ukazania roli, jaką pełniły klasztory w bułgarskim systemie edukacji. Na dowód istnienia szkół przyklasztornych Badacz znalazł raptem jedną wzmiankę. Jednak kierując się własną logiką, wysuwa on w pełni słuszne przypuszczenie, że takich szkół musiało być więcej.

W podsumowaniu części na temat społecznej roli monastycyzmu bułgarskiego, Jan M. Wolski konkluduje, że nie umie udzielić jednoznacznej odpowiedzi na pytanie, czy zaangażowanie się mnichów w sprawy świeckie było sprzeniewierzeniem się powołaniu. Jego zdaniem dostępne źródła na to nie pozwalają (s. 149-150).

Cenną i ważną częścią tej rozprawy, która bez wątpienia zainteresuje badaczy późnośredniowiecznego monastycyzmu na Bałkanach jest aneks źródłowy (s. 153189). Zawiera on fragmenty Nomokanonu CIAI 1160 w języku cerkiewno-słowiańskim, w którym zebrano reguly i pouczenia dotyczące mnichów.

Książkę uzupełniają: wykaz skrótów (s. 191-193), bibliografia (s. 195-216), streszczenie w języku angielskim (s. 217-218) oraz indeksy: osób (s. 219-222), nazw geograficznych, miejscowych i etnicznych (s. 223-225). 
Zaprezentowana publikacja podejmuje zagadnienia pojawiające się dotąd jedynie sporadycznie w polskiej historiografii i w sposób niedostateczny przebadane przez autorów bułgarskich, czy szerzej ujmując zagranicznych, przez co ona zyskuje charakter nowatorski. Zaletą niniejszej książki jest przejrzysty i logiczny układ treści. Wydaje się jednak, że mogłaby ona trafić do znacznie szerszego grona odbiorców niż tylko slawiści i bizantyniści, gdyby cytowane w niej fragmenty źródeł w języku cerkiewno-słowiańskim zostały przetłumaczone na język polski. Należy jednak wyrazić nadzieję, że tak się stanie wraz z jej kolejnym wydaniem. Jestem przekonany, że ta bardzo interesująca i ważna publikacja znajdzie miejsce w szerokim obiegu naukowym, stając się przyczynkiem do dyskusji nad ewolucją ruchu monastycznego od momentu jego powstania aż do czasów późnego średniowiecza.

Andrzej R. Hołasek 
